Review

\title{
Battle Against Cancer: An Everlasting Saga of p53
}

\section{Qian Hao ${ }^{1, *}$ and William C. Cho ${ }^{2, *}$}

1 School of Continuing Studies, Tulane University, New Orleans, LA 70118, USA

2 Department of Clinical Oncology, Queen Elizabeth Hospital, Hong Kong 999077, China

* Authors to whom correspondence should be addressed;

E-Mails: qhao@tulane.edu or josiehao@gmail.com (Q.H.); williamcscho@gmail.com (W.C.C.)

External Editor: Paul Evans

Received: 20 September 2014; in revised form: 23 October 2014 / Accepted: 25 November 2014 / Published: 1 December 2014

\begin{abstract}
Cancer is one of the most life-threatening diseases characterized by uncontrolled growth and spread of malignant cells. The tumor suppressor p53 is the master regulator of tumor cell growth and proliferation. In response to various stress signals, p53 can be activated and transcriptionally induces a myriad of target genes, including both protein-encoding and non-coding genes, controlling cell cycle progression, DNA repair, senescence, apoptosis, autophagy and metabolism of tumor cells. However, around $50 \%$ of human cancers harbor mutant p53 and, in the majority of the remaining cancers, p53 is inactivated through multiple mechanisms. Herein, we review the recent progress in understanding the molecular basis of p53 signaling, particularly the newly identified ribosomal stress $-\mathrm{p} 53$ pathway, and the development of chemotherapeutics via activating wild-type p53 or restoring mutant p53 functions in cancer. A full understanding of p53 regulation will aid the development of effective cancer treatments.
\end{abstract}

Keywords: p53; mutant p53; MDM2; ribosomal stress; transcription; cancer chemotherapeutics

\section{Introduction}

Tumorigenesis is promoted by deregulation or mutation of genes involved in cell division control. The tumor suppressor p53 is the most prominent and extensively studied example due to its dominating effect on tumor cell growth and proliferation [1-5]. Since its discovery in 1979, p53 has 
been regarded as an oncogene as its overexpression could immortalize primary cells, and could promote transformation of such cells through cooperating with other established oncoproteins, such as H-RAS, a GTPase involved in many signal transduction pathways [6-8]. Although there was discussion during the 1980 s that $p 53$ might possess tumor suppressive activity, $p 53$ was not redefined as a tumor suppressor gene until the wild-type $p 53$ sequence was confirmed at the end of the 1980s $[9,10]$. Baker et al. [11] found that wild-type $p 53$ is frequently lost or mutated in human colorectal cancer, and that these tumor cells therefore no longer retain wild-type p53. This could be the reason why the mutant, but not wild-type, p53 was firstly cloned from cancer cells. To date, tens of thousands of studies have demonstrated that p53 expands its tumor suppressive functions to most, if not all, aspects of cancer development. p53 is a transcriptional factor that regulates a large number of target genes involved in cell cycle arrest, apoptosis, senescence, autophagy and metabolism [12] (Figure 1), although some effects of p53 are independent of its transcriptional activity [13-15]. Thus, tumor cells need to employ additional mechanisms to negate p53 functions in favor of their survival. Indeed, more than $50 \%$ of human cancers harbor mutant p53 [16-18], while in most of the remaining cancers, p53 activity is markedly impaired through, for instance, overexpression of the E3-ligase MDM2 (murine double minute 2, also known as HDM2 for its human ortholog) [19,20]. MDM2 is a major inhibitor of p53 found to be overexpressed or amplified in multiple cancers and physically interact with both $N$ - and $C$-termini of p53 [21]. At least three principal mechanisms have been demonstrated for MDM2-mediated inactivation of p53; MDM2: abrogates transcriptional activity of p53 through directly binding to its $\mathrm{N}$-terminal transactivation domain [22]; destabilizes p53 by promoting its poly-ubiquitination and proteasomal degradation [23-25]; and prompts nuclear export of p53 by inducing its mono-ubiquitination [26]. The importance of MDM2-mediated p53 inactivation has been verified by elegant studies showing that genetic disruption of the $p 53$ gene rescues the lethal phenotype of Mdm2 knock-out mice [27,28] and that inhibition of MDM2 results in robust p53 activation in tumor cells [29,30]. Importantly, several other mechanisms have been demonstrated to overcome the oncogenic effect of p53 inactivation. For instance, depletion of Skp2, an E3-ligase of the G1 Cyclin-Cdk protein kinase inhibitor p27, has been found to prevent prostate tumorigenesis caused by inactivation of p53 and another tumor suppressor $\mathrm{pRb}[31]$.

\section{Activation of p53 upon Ribosomal Stress}

As mentioned above, the tumor suppressor p53 is often inactivated in tumor cells, thus, reactivation of p53 upon stress signaling is an important strategy to inhibit tumor cell growth and proliferation. For example, DNA damage triggers p53 phosphorylation by ATM, ATR, DNA-PK, Chk, Chk2, etc. [32-34] and acetylation by p300/CBP, PCAF, hMOF and Tip60 [35-39], which disrupts the interaction of MDM2 and p53, consequently leading to p53 activation [40]. In addition, p53 can also be stabilized and activated in response to hypoxia or low oxygen tension. HIF $1 \alpha$ is the first candidate that was found to directly associate with and stabilize p53 under hypoxia $[41,42]$. Other studies have also shown that hypoxia stimulates ATR-CHK1 cascade-mediated phosphorylation of p53 [43] and the MDM2 partner, MDMX [44], resulting in p53 activation.

Over the past decade, ribosomal stress (also known as nucleolar stress) has emerged and been gradually appreciated as an essential cellular pressure that can induce p53 activation and resultant 
tumor growth inhibition [30,45]. Ribosome biogenesis, the process of producing the cellular translational machinery - the ribosome - requires a coordinated network of ribosomal proteins (RPs), rRNAs and non-ribosomal factors. Principally, RPs are synthesized in the cytoplasm and transported to the nucleolus; rRNAs are synthesized in the nucleolus or nucleoplasm (only for 5S rRNA). The pre-ribosomes are assembled in the nucleolus with the assistance of non-ribosomal factors, and consequently exported to the cytoplasm forming the mature ribosome. Stimuli that perturb any step of this process can cause ribosomal stress [30,45]. These stimuli are categorized into three groups: (1) chemical agents inhibiting rRNA synthesis; (2) nutrient depletion limiting energy availability for ribosome biogenesis; and (3) dysfunction of RP-encoding genes or non-ribosomal genes required for rRNA synthesis or ribosome assembly [45]. One may raise the question of how ribosomal stress can trigger p53 activation. A series of studies have demonstrated that ribosomal stress results in the accumulation of ribosome-free RPs in the nucleoplasm, and as such, they bind to MDM2 and inhibit its E3-ligase activity towards p53 [30,45].

Figure 1. Summary of the p53 pathway. Under normal conditions, the major negative regulator, MDM2, binds to p53 and inhibits its transcriptional activity. In response to various stress signals, including oncogenic stress, hypoxia, ribosomal stress, DNA damage, telomere erosion and others, p53 can be activated, principally through abrogating MDM2 inhibition, and transcriptionally induces the expression of an array of target genes leading to different cellular outcomes. Three representative target genes dictating each cell fate are listed.

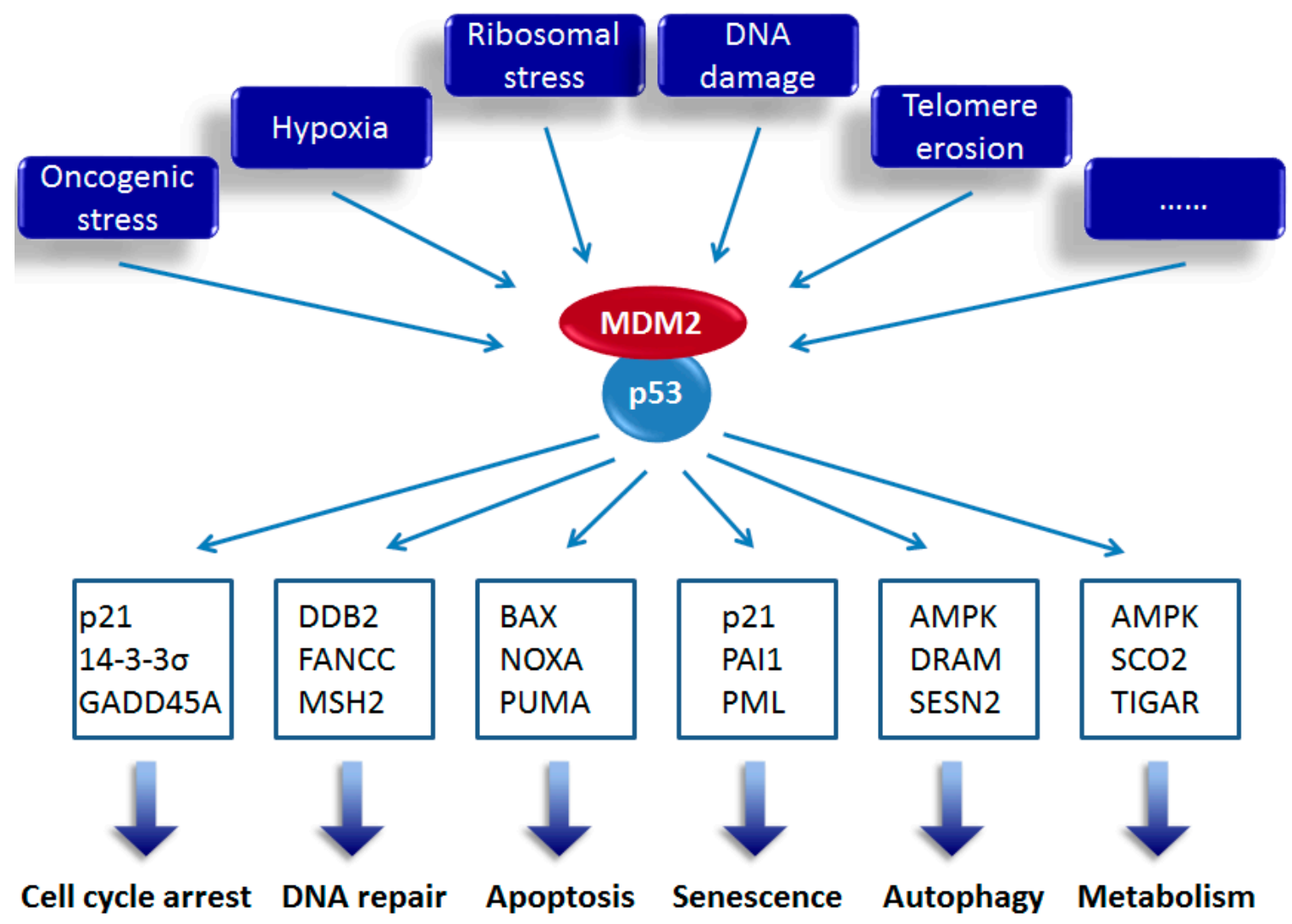

Although the association of RPL5 and MDM2 was initially identified in 1994 [46], the physiological function of this interaction had been unclear until three independent groups found that several RPs, including RPL11, RPL5 and RPL23, could directly bind to MDM2 and inhibit MDM2-mediated p53 
ubiquitination and proteasomal degradation in response to ribosomal stress triggered by actinomycin D (Act D) [47-51]. Thereafter, increasing attention has been drawn to the newly discovered field and a dozen of RPs, including RPL6 [52], RPL26 [53], RPL37 [54], RPS3 [55], RPS7 [56,57], RPS14 [58], RPS15 [54], RPS20 [54], RPS25 [59], RPS26 [60], RPS27 [61] and RPS27A [62], have been identified to interact with MDM2 and repress its inhibitory function towards p53 during the past ten years. Although most of these RPs can stabilize p53 by preventing its ubiquitination and degradation from MDM2, some of them have been found to activate p53 through additional mechanisms. For instance, RPL26 can bind to the $5^{\prime}$ untranslated region (UTR) of p53 mRNA and augment p53 translation [63]. The association of MDM2 with RPL26 was shown to attenuate the binding of RPL26 to p53 mRNA, as thus suppressing RPL26-mediated augmentation of p53 protein synthesis [64]. Another example is RPL11 that not only stabilizes p53 but also boosts p53 transcriptional activity [65]. It has been found that RPL11 can be recruited on the p53 target gene promoters via its binding to MDM2, and therefore relieve MDM2-mediated transcriptional repression of p53 [65]. Interestingly, several RPs, such as RPL6, RPL26, RPS25, RPS27 and RPS27A, are found to be transcriptionally repressed by $\mathrm{p} 53$ or post-transcriptionally downregulated by MDM2, thereby forming a negative feedback loop $[52,59,61,62,64]$. A recent in vivo study has gracefully validated the physiological significance of RPs in ribosomal stress-triggered p53 activation. In this study, Macias et al. [66,67] generated mice carrying a mutation of $\mathrm{Mdm} 2^{\mathrm{C} 305 \mathrm{~F}}$ which was defective in binding to RPL5 and RPL11, and found that p53 activation in response to ribosomal stress was markedly impaired, whereas p53 response to DNA damage was normal, in these mutant mice [66].

Growing evidence has demonstrated the central role of the RP-MDM2-p53 pathway in controlling cancer development. For instance, Sasaki et al. [68] found that the oncogenic protein PICT1 attenuates p53 activation upon stress by sequestering RPL11 in the nucleolus and thus blocking the RPL11-MDM2 interaction. Reversely, in PICT1-deficient cells, p53 ubiquitination and degradation was dramatically repressed by increased binding of RPL11 to MDM2 [68]. Another oncoprotein SRSF1 was found to stabilize p53 by abrogating its MDM2-mediated degradation via direct binding to RPL5 [69]. In addition, the ARF tumor suppressor has been shown to activate p53 through an RP-MDM2-p53 cascade [70]. ARF can directly bind to RPL11 and this interaction enhances p53 activation in response to either oncogenic or ribosomal stress. These two nucleolar proteins work together to form a complex with MDM2 and p53, and tremendously improves the stability and activity of p53. Also, high expression of ARF causes accumulation of ribosome-free RPL11, thus bolstering the RPL11-MDM2 interaction and consequent p53 activation [70]. Ling Zhi-8 (LZ-8), an immunomodulatory protein exhibiting antitumor activity, derived from medicinal mushroom Ganoderma lucidum [71] can induce p53-dependent $\mathrm{G}_{1}$ cell cycle arrest and suppress proliferation of lung cancer cells by triggering ribosomal stress and RPS7-MDM2 binding [72]. The above studies have underscored the pivotal role of RP in connecting other important proteins to the p53 pathway. Hence, it would be interesting to profile the protein interactomes of the MDM2-binding RPs, which will largely improve our understanding of the regulatory network of the RP-MDM2-p53 pathway.

Interestingly, post-translational modifications (PTM) of RPs have been found to be essential for MDM2-p53 regulation. Under normal conditions, the NEDD8-mediated RPL11 NEDDylation promotes its nucleolar localization, whereas ribosomal stress can induce de-NEDDylation of RPL11 which subsequently relocalizes to the nucleoplasm leading to p53 activation $[65,73]$. In contrast, 
NEDDylation of RPS14 positively prompts its activity to release p53 from MDM2 inhibition [74]. Additionally, several RPs can also be ubiquitinated by MDM2 leading to either impaired or prompted p53 activation. For instance, ubiquitinated RPL26 tends to be degraded resulting in impaired p53 activation [64], whereas ubiquitinated RPS7 promotes further activation of p53 to a greater extent and elicits apoptosis upon ribosomal stress [56]. Acetylation and phosphorylation are two important events that extensively influence various cellular processes during tumor growth, including MDM2-p53 signaling [40]. Although several RPs can be acetylated (e.g., RPL24 [75]) or phosphorylated (e.g., RPS6 [76]), less attention has been paid to the possible role of acetylation or phosphorylation of RPs in the regulation of the MDM2-p53 pathway. Recently, a proteomic analysis of nucleolar protein acetylation revealed that many MDM2-binding RPs, including RPL5, RPL11, RPL26, RPS3, RPS7 and RPS27A, could potentially be acetylated [77], which implies that acetylation of these RPs may be involved in the MDM2-p53 regulation. This is certainly an intriguing and important question that would be addressed in future study.

Taken together, this gradually appreciated RP-MDM2-p53 pathway is subjected to multiple regulations, including RP-associating cofactors and PTMs, and has been playing an increasingly essential role in controlling tumorigenesis.

\section{Roles of p53 and Mutant p53 Target Genes}

It has been well documented that most p53 functions are mediated by transcriptional activation of its target genes in response to various stress signals (Figure 1), although cytoplasmic p53 was also shown to directly bind to, for example, BAX to trigger mitochondrial outer membrane permeabilization (MOMP) and apoptosis [78]. There are four sets of experimental criteria for identifying a p53 target gene [12]. First, one or several p53 responsive elements (REs) are required close to or within the gene. A consensus motif, 5'-RRRCWWGYYY-3', has been identified in p53 REs where $\mathrm{R}$ is a purine, $\mathrm{Y}$ is a pyrimidine, $\mathrm{W}$ is either $\mathrm{A}$ or $\mathrm{T}$ (adenine or thymine), $\mathrm{G}$ is guanine and $\mathrm{C}$ is cytosine [79,80]. A canonical p53 RE contains two consensus motifs separated by a spacer of 0-21 base pairs; Second, the mRNA level of the candidate gene must be upregulated or downregulated by p53; Third, by engineering the RE from the candidate gene into a vector encoding a reporter gene (e.g., luciferase), p53 can regulate the reporter gene expression; Finally, p53 protein specifically and directly associates with the RE in the DNA through chromatin immunoprecipitation (ChIP) assay. Thus far, hundreds of p53 target genes have been identified, which are involved in a wide variety of cellular processes, including cell cycle arrest, DNA repair, apoptosis, senescence, autophagy, metabolic homeostasis, etc. [12,29,81]. In cells exposed to mild stress signals, p53 induces protective and pro-survival responses, such as temporary cell cycle arrest, allowing cells to repair their DNA and maintain the genome integrity. Alternatively, intensive stress signals provoke p53-mediated irreversible responses, such as apoptosis and senescence, which eliminate irreparable damaged or malignant cells.

What accounts for $\mathrm{p} 53$ selective activation of its target genes dictating diverse cell fates is an intriguing question. A number of studies have demonstrated factors that regulate target gene selection by p53 [82]. Several studies suggest that p53 binds to its target gene promoters with varying affinities-promoters of target genes controlling cell cycle retain high affinity to $\mathrm{p} 53$, whereas apoptotic target gene promoters 
have low affinity [83-85]. It is therefore proposed that a low level of p53 induced by mild stress signals is only able to activate target genes involved in cell cycle control, while a high level of p53 stimulated by potent stress signals can activate apoptotic target genes. However, another study reported that a portion of apoptotic genes, such as PUMA, p53AIP1 and NOXA, also have high-affinity p53 REs [86]. Hence, other mechanisms must also be responsible for p53 target gene selectivity. Upon stress signals, p53 undergoes a series of PTMs which have been shown to play an essential role in p53-dependent cell fate determination. For example, Ser-46 phosphorylation is required for p53-dependent transcriptional activation of the apoptotic gene $p 53 A I P 1$, and Ser-46 to Alanine mutation that prevents phosphorylation of this site abolishes p53-mediated activation of p53AIP1, but not the cell cycle gene p21 [87]. Another example is acetylation of Lys-120 that is crucial to p53-triggered apoptosis. It has been found that Lys-120 to Arginine mutant retains the ability to transcriptionally activate $p 21$, but fails to induce the expression of the apoptotic target genes, PUMA and BAX [38,39]. Additionally, several p53-interacting proteins have also been shown to control specific transactivation of p53 target genes. One of the prominent examples is the ASPP protein family, including ASPP1, ASPP2 and iASPP, that directly binds to the central core domain of p53 [88]. The association of ASPP1 and ASPP2 with p53 specifically prompts p53-dependent apoptotic gene activation, while iASPP opposes this effect $[88,89]$. Altogether, numerous mechanisms have been found to be associated with selective activation of target genes by $\mathrm{p} 53$, and thorough elaboration of these mechanisms of cell fate determination would clearly contribute to the development of therapeutic strategies for human cancer.

Aside from the aforementioned protein-encoding genes, p53 can also induce non-coding RNA genes, including microRNA (miRNA) and long non-coding RNA genes. miRNAs are small noncoding RNAs, 9-22 nucleotides in length, which usually bind to the 3' UTR of target mRNAs and post-transcriptionally silence their expression. Principally, the generation of a functional miRNA includes two steps, transcription and maturation. RNA Pol II or RNA Pol III-mediated transcription produces the miRNA precursor, pri-miRNA, which undergoes further processing to generate mature miRNA. Only the mature miRNA is employed to form the RNA-induced silencing complex (RISC) to inhibit the target gene expression [90]. Interestingly, p53 has been found to not only transcriptionally regulate miRNA gene expression [91], but also modulate the maturation of miRNA [92]. The processing of pri-miRNA requires the nuclear RNase III Drosha complex which contains Drosha, DGCR8 and several RNA-associated proteins including the DEAD box RNA helicases p68. A recent study has shown that p53 is able to facilitate the formation of the Drosha complex by directly associating with p68, consequently enhancing the maturation of several tumor suppressive miRNAs [92]. Thus far, a number of p53-regulated miRNAs have been identified and shown to be involved in multiple cellular processes, including cell cycle progression, DNA repair, cell survival, epithelial-mesenchymal transition (EMT), stemness, metabolism and angiogenesis [93,94]. For example, miR-34a-c, a family of miRNAs transcriptionally activated by p53, have been shown to elicit cell cycle arrest by targeting cell cycle-related genes, such as, CDK4, CDK6, CCNE2 and MET [95,96]. Also miR-34s can induce apoptosis by down-regulating several well-documented anti-apoptotic genes, including BCL2, BIRC3 and DcR3 [96-98]. Notably, the tumor suppressive function of miR-34s also attributes to its activity to inhibit other important oncogenic pathway, including MYC [99], E2F [100], Wnt [101], Snail1 [102], MAGE-A [103] and c-Kit [104]. Of interest, several studies revealed that p53 also transcriptionally induces large intergenic non-coding RNAs (LincRNAs) [105,106], which are regarded as master gene 
regulators involving chromatin remodeling and histone modifications. For instance, lincRNA-p21 can be activated by p53 and serves as a global repressor of oncogenic genes thus leading to the induction of apoptosis [106].

When talking about wild-type p53, it is impossible not to mention mutant $\mathrm{p} 53$. Most cancer-associated inactivation of p53 results from missense mutations, single base-pair substitutions leading to the translation of a different amino acid that may either annihilate the wild-type p53 function or endow the mutant p53 with new functions. A seminal study has recently found that the elevated expression of the DNA cytosine deaminase APOBEC3B in breast cancer may contribute to the mutagenesis of p53 [107]. Because of the essential role of p53 in controlling cell survival as a transcription factor, it is interesting, but not surprising, that the vast majority of the missense mutations occur in the DNA binding domain (DBD) of p53. Among these mutations, the six most frequently mutated residues, including R175, G245, R248, R249, R273 and R282, are regarded as "hot spot" residues [16,18]. Mutations in the DBD disrupt the DNA binding ability of p53, thus mutant p53 usually loses transcriptional activity and, in many cases, causes a dominant-negative effect on the remaining wild-type allele through forming mutant/wild-type p53 co-tetramers [108] or supra-tetrameric aggregates [109]. Most interestingly, studies have demonstrated that mutant p53 may also acquire "gain-of-function", not present in wild-type p53. Principally, four mechanisms underlie gain-of-function of mutant p53 [16-18]. Firstly, mutant p53 can directly bind to p53 family proteins, p63 and p73, and inhibit their transcriptional activity [110-113]. Secondly, the interaction of mutant p53 with other transcription factors, such as NF-Y [114], SREBP-2 [115], Sp1 [116], ETS1 [117], ETS2 [118] and VDR [119], leads to indirect regulation of their target genes. Most of the known mutant p53 target genes are transcriptionally regulated via this indirect manner. Thirdly, mutant p53 can recognize and associate with structure-specific DNA, e.g., nuclear matrix attachment regions (MARs) [120,121], resulting in transcriptional modulation of target gene expression. Lastly, mutant p53 can also bind to non-transcription factors, such as TopBP1 [122], Pin1 [123] and others [18]. A large number of mutant p53 target genes have been identified and found to support tumor cell survival and proliferation by inhibiting apoptosis, promoting chemoresistance and regulating metabolism as well as cell-cell/cell-extracellular matrix (ECM) signaling [18]. In addition to these target gene-mediated functions, mutant p53 has also been shown to contribute to genomic instability, inflammation, migration, invasion, angiogenesis and metastasis $[17,18]$, which places it in the core position of tumorigenesis. Therefore, targeting mutant p53 could be an important therapeutic strategy, with great promise, for human cancers bearing mutant p53.

\section{Drug Development}

As the essential role of p53 is killing tumor cells, numerous strategies have been developed to activate p53 or restore mutant p53 function for cancer therapy. Although some traditional genotoxic chemotherapeutic drugs, such as Adriamycin and platinum-based drugs, activate the p53 pathway, they also cause systemic toxicity and induce multidrug resistance. It is therefore critically important that non-genotoxic chemotherapeutics be developed to specifically target $\mathrm{p} 53$. Because of the central role of MDM2 in modulating p53 activity, much attention has been devoted to developing MDM2 inhibitors that can specifically release p53 from MDM2 repression. The ground-breaking work in this field is the development of Nutlin, a small molecule disrupting MDM2-p53 interaction without causing 
genotoxicity [124]. It has been shown that Nutlin mimics a MDM2-binding p53 peptide that competitively associates with MDM2 and prevents MDM2-p53 interaction, resulting in robust non-genotoxic activation of p53 [124]. The Nutlin derivative RG7112 (RO5045337) has been developed by Hoffmann-La Roche and is the first specific p53 activator that advanced to clinical trials. It is a more potent inhibitor of MDM2-p53 interaction, yet through the similar mechanism, compared to Nutlin [125]. There are also other promising compounds that antagonize MDM2 function entering Phase I trials [126], including RO5503781, SAR405838, CGM097 and MK-8242 (Table 1).

One of the important negative regulators, the SIRT1 deacetylase, has been shown to maintain the deacetylated status of p53, and thus promote its MDM2-mediated degradation [127,128]. It has also been revealed that developing compounds against SIRT1 could be an alternative strategy for activation of p53. For example, Tenovins can inhibit activities of SIRT1 and SIRT2, and thereby stabilize and activate p53. Although Tenovins suppress growth of p53-null or mutant cancer cells, wild-type p53 do sensitize cells to Tenovins-induced apoptosis [129]. Another compound, Inauhzin, has recently been identified as a specific SIRT1 inhibitor. It can directly bind to SIRT1 and inhibit its deacetylase activity leading to dramatic p53 activation and p53-dependent apoptosis and cell growth arrest at a very low concentration of two micromolar. This study also showed that Inauhzin does not bind to DNA and is thus unable to cause genotoxicity [130]. Importantly, both compounds were shown to inhibit growth of xenograft tumors in mice $[129,130]$, indicating that they are potential drug candidates that require further preclinical studies.

As mutations in p53 occur in up to $50 \%$ of human cancers, how to restore mutant p53 protein to a transcriptionally functional conformation becomes a hot topic and promising strategy for the treatment of cancers harboring mutant $\mathrm{p} 53$. One of the most successful compounds is PRIMA-1 ${ }^{\mathrm{MET}}$ (also known as APR-246). While PRIMA-1 ${ }^{\text {MET }}$ can induce cell death independently of p53 [131-133], it has been found to restore mutant $\mathrm{p} 53(\mathrm{R} 273 \mathrm{H}$ and $\mathrm{R} 175 \mathrm{H})$ function in vitro and in vivo by covalently binding to mutant $\mathrm{p} 53$ and mediating modification of its thiol groups, and has completed a Phase I clinical trial [134-137]. Fersht and colleagues designed two compounds, PK083 and PK7088, to target mutant p53 Y220C [138,139]. They showed that these two compounds raise the melting temperature of mutant p53 and restore mutant p53 protein to a wild-type conformation, consequently leading to cell cycle arrest, apoptosis and growth inhibition $[138,139]$. Recently, the thiosemicarbazone family compound NSC319726 has been identified to convert $\mathrm{p} 53^{\mathrm{R} 175}$ mutant into a wild-type structure by chelating the zinc ion and changing the redox state, and therefore rescues transcriptional function of $\mathrm{p} 53^{\mathrm{R} 175}$ mutant resulting in tumor suppression [140].

There are certainly many other compounds, in addition to those mentioned above, targeting p53 or the mutant p53 pathway [141]; however, it requires great efforts and often takes a very long time to translate the basic biomedical research into effective medicines. The more detailed the elucidation of the molecular basis of p53 activation is, the greater the chance of more efficient and specific therapeutic strategies being developed for the benefit of patients with cancer. 
Table 1. Summary of compounds activating p53 or reactivating mutant p53 discussed in the essay.

\begin{tabular}{|c|c|c|c|c|c|}
\hline ID & Company & Status & Mechanism & In vivo Test & References \\
\hline $\begin{array}{c}\text { RG7112 } \\
\text { (RO5045337) }\end{array}$ & $\begin{array}{l}\text { Hoffmann- } \\
\text { La Roche }\end{array}$ & Phase I & $\begin{array}{l}\text { Inhibition of } \\
\text { MDM2-p53 } \\
\text { interaction }\end{array}$ & $\begin{array}{c}\text { Advanced } \\
\text { malignancies, } \\
\text { except leukemia }\end{array}$ & [125] \\
\hline $\begin{array}{c}\text { MI-773 } \\
(\text { SAR405838) }\end{array}$ & $\begin{array}{l}\text { Sanofi- } \\
\text { Aventis }\end{array}$ & Phase I & $\begin{array}{l}\text { Inhibition of } \\
\text { MDM2-p53 } \\
\text { interaction }\end{array}$ & $\begin{array}{l}\text { Advanced } \\
\text { cancer }\end{array}$ & [126] \\
\hline CGM097 & Novartis & Phase I & $\begin{array}{l}\text { Inhibition of } \\
\text { MDM2-p53 } \\
\text { interaction }\end{array}$ & $\begin{array}{c}\text { Selected } \\
\text { advanced and } \\
\text { refractory solid } \\
\text { tumors }\end{array}$ & [126] \\
\hline MK-8242 & Merck & Phase I & $\begin{array}{l}\text { Inhibition of } \\
\text { MDM2-p53 } \\
\text { interaction }\end{array}$ & - & [126] \\
\hline RO5503781 & $\begin{array}{l}\text { Hoffmann- } \\
\text { La Roche }\end{array}$ & Phase I & $\begin{array}{l}\text { Inhibition of } \\
\text { MDM2-p53 } \\
\text { interaction }\end{array}$ & $\begin{array}{l}\text { Soft tissue } \\
\text { sarcoma; } \\
\text { leukemia }\end{array}$ & [142] \\
\hline Tenovin & - & Preclinical & $\begin{array}{c}\text { Inhibition of } \\
\text { Sirt1 and Sirt } 2 \\
\text { activity }\end{array}$ & - & [129] \\
\hline Inauhzin & - & Preclinical & $\begin{array}{l}\text { Inhibition of } \\
\text { Sirt1 activity }\end{array}$ & - & [130] \\
\hline $\begin{array}{l}\text { PRIMA-1 } \\
\text { /APR-246 }\end{array}$ & Aprea AB & Phase I/II & $\begin{array}{l}\text { Reactivate } \\
\text { mutant p53 }\end{array}$ & $\begin{array}{c}\text { Refractory } \\
\text { hematologic } \\
\text { malignancies } \\
\text { and prostate } \\
\text { cancer }\end{array}$ & [136] \\
\hline PK083 & - & Preclinical & $\begin{array}{c}\text { Reactivate } \\
\text { mutant p53 } \\
\text { Y220C } \\
\end{array}$ & - & [138] \\
\hline PK7088 & - & Preclinical & $\begin{array}{c}\text { Reactivate } \\
\text { mutant p53 } \\
\text { Y220C } \\
\end{array}$ & - & [139] \\
\hline NSC319726 & - & Preclinical & $\begin{array}{c}\text { Reactivate } \\
\text { mutant p53 } \\
\text { R175H } \\
\end{array}$ & - & [140] \\
\hline
\end{tabular}

\section{Conclusions and Challenges}

As one of the most important tumor suppressors, p53 can be activated in response to multiple stress signals leading to transcriptional activation of a large group of target genes and consequently suppression of tumorigenesis principally through inducing cell cycle arrest, senescence, apoptosis and metabolic changes. Therefore, the p53 pathway has become an ideal target for the development of chemotherapeutics for cancer. While the achievements in dissecting the p53 signaling pathway opens a 
promising avenue which might lead to our final success in the battle against cancer, these seminal studies also raise a great many questions. For example, acetylation of several lysine residues, such as Lys-120 and Lys-164, are critical for transcriptional activity of p53. To assess whether full activity of p53 is essential for its tumor suppressive ability, an animal model with triple lysine to arginine mutations of Lys-117, Lys-161 and Lys-162 (equivalent to human Lys-120, Lys-164 and Gln-165) was generated [143]. In the study, p53 ${ }^{3 \mathrm{KR}}$ was shown to partially lose its transcriptional activity leading to abrogated cell cycle arrest, apoptosis and senescence upon DNA damage while retaining tumor suppressive function by inducing a range of target genes involved in metabolic regulation [143]. Another study showed that inactivation of TAD1, one of the two distinct transactivation domains (TADs) of p53, abolishes acute DNA damage-triggered p53 activation whereas the tumor suppressive function of p53 remains intact [144,145]. Therefore, it is interesting and challenging whether activation of metabolic target genes is sufficient for p53-dependent tumor suppression, and whether therapeutic strategies can be developed by partially attenuating p53 activity and thus reducing DNA damage-caused, p53-dependent detrimental side effects on normal tissues. Additionally, more questions are posed based on what has been learned about p53. Do any other stress signals, besides those mentioned above, activate p53 pathway? How many RPs can bind to MDM2 upon ribosomal stress? What other target genes does p53 regulate? Does p53 regulate the chromatin landscape of its target genes? What is the mechanism underlying the frequent mutation of the "hot spot" residues of p53 gene? Is there any stress signal that can repress mutant p53 function? Do PTMs regulate mutant p53 functions? Can we design compounds that specifically control tumor cell fate? Hence, tremendous efforts are needed to elucidate these enigmas, and thereby hopefully lead to the development of effective compounds or strategies to treat cancer.

\section{Acknowledgments}

We thank Xiang Zhou, Department of Biochemistry \& Molecular Biology of Tulane University, for very helpful instruction and proofreading the manuscript.

\section{Author Contributions}

Qian Hao drafted the manuscript; William C. Cho initiated the idea and drafted part of the manuscript.

\section{Conflicts of Interest}

The authors declare no conflict of interest.

\section{References}

1. Lane, D.P.; Crawford, L.V. T antigen is bound to a host protein in SV40-transformed cells. Nature 1979, 278, 261-263.

2. Linzer, D.I.; Levine, A.J. Characterization of a 54K dalton cellular SV40 tumor antigen present in SV40-transformed cells and uninfected embryonal carcinoma cells. Cell 1979, 17, 43-52.

3. Kress, M.; May, E.; Cassingena, R.; May, P. Simian virus 40-transformed cells express new species of proteins precipitable by anti-simian virus 40 tumor serum. Virology 1979, 31, 472-483. 
4. Melero, J.A.; Stitt, D.T.; Mangel, W.F.; Carroll, R.B. Identification of new polypeptide species (48-55K) immunoprecipitable by antiserum to purified large $\mathrm{T}$ antigen and present in SV40-infected and -transformed cells. Virology 1979, 93, 466-480.

5. Smith, A.E.; Smith, R.; Paucha, E. Characterization of different tumor antigens present in cells transformed by simian virus 40. Cell 1979, 18, 335-346.

6. Eliyahu, D.; Raz, A.; Gruss, P.; Givol, D.; Oren, M. Participation of p53 cellular tumour antigen in transformation of normal embryonic cells. Nature 1984, 312, 646-649.

7. Jenkins, J.R.; Rudge, K.; Currie, G.A. Cellular immortalization by a cDNA clone encoding the transformation-associated phosphoprotein p53. Nature 1984, 312, 651-654.

8. Parada, L.F.; Land, H.; Weinberg, R.A.; Wolf, D.; Rotter, V. Cooperation between gene encoding p53 tumour antigen and ras in cellular transformation. Nature 1984, 312, 649-651.

9. Eliyahu, D.; Goldfinger, N.; Pinhasi-Kimhi, O.; Shaulsky, G.; Skurnik, Y.; Arai, N.; Rotter, V.; Oren, M. Meth A fibrosarcoma cells express two transforming mutant p53 species. Oncogene 1988, 3, 313-321.

10. Finlay, C.A.; Hinds, P.W.; Tan, T.H.; Eliyahu, D.; Oren, M.; Levine, A.J. Activating mutations for transformation by p53 produce a gene product that forms an hsc70-p53 complex with an altered half-life. Mol. Cell. Biol. 1988, 8, 531-539.

11. Baker, S.J.; Fearon, E.R.; Nigro, J.M.; Hamilton, S.R.; Preisinger, A.C.; Jessup, J.M.; van Tuinen, P.; Ledbetter, D.H.; Barker, D.F.; Nakamura, Y; et al. Chromosome 17 deletions and p53 gene mutations in colorectal carcinomas. Science 1989, 244, 217-221.

12. Riley, T.; Sontag, E.; Chen, P.; Levine, A. Transcriptional control of human p53-regulated genes. Nat. Rev. Mol. Cell Biol. 2008, 9, 402-412.

13. Vogelstein, B.; Lane, D.; Levine, A.J. Surfing the p53 network. Nature 2000, 408, 307-310.

14. Vousden, K.H.; Lane, D.P. p53 in health and disease. Nat. Rev. Mol. Cell Biol. 2007, 8, 275-283.

15. Marchenko, N.D.; Moll, U.M. The role of ubiquitination in the direct mitochondrial death program of p53. Cell Cycle 2007, 6, 1718-1723.

16. Brosh, R.; Rotter, V. When mutants gain new powers: News from the mutant p53 field. Nat. Rev. Cancer 2009, 9, 701-713.

17. Muller, P.A.; Vousden, K.H. p53 mutations in cancer. Nat. Cell Biol. 2013, 15, 2-8.

18. Freed-Pastor, W.A.; Prives, C. Mutant p53: One name, many proteins. Genes Dev. 2012, 26, 1268-1286.

19. Momand, J.; Zambetti, G.P.; Olson, D.C.; George, D.; Levine, A.J. The mdm-2 oncogene product forms a complex with the p53 protein and inhibits p53-mediated transactivation. Cell 1992, 69, 1237-1245.

20. Oliner, J.D.; Kinzler, K.W.; Meltzer, P.S.; George, D.L.; Vogelstein, B. Amplification of a gene encoding a p53-associated protein in human sarcomas. Nature 1992, 358, 80-83.

21. Poyurovsky, M.V.; Katz, C.; Laptenko, O.; Beckerman, R.; Lokshin, M.; Ahn, J.; Byeon, I.J.; Gabizon, R.; Mattia, M.; Zupnick, A; et al. The $\mathrm{C}$ terminus of p53 binds the $N$-terminal domain of MDM2. Nat. Struct. Mol. Biol. 2010, 17, 982-989.

22. Oliner, J.D.; Pietenpol, J.A.; Thiagalingam, S.; Gyuris, J.; Kinzler, K.W.; Vogelstein, B. Oncoprotein MDM2 conceals the activation domain of tumour suppressor p53. Nature 1993, $362,857-860$. 
23. Haupt, Y.; Maya, R.; Kazaz, A.; Oren, M. Mdm2 promotes the rapid degradation of p53. Nature 1997, 387, 296-299.

24. Kubbutat, M.H.; Jones, S.N.; Vousden, K.H. Regulation of p53 stability by Mdm2. Nature 1997, 387, 299-303.

25. Fuchs, S.Y.; Adler, V.; Buschmann, T.; Wu, X.; Ronai, Z. Mdm2 association with p53 targets its ubiquitination. Oncogene 1998, 17, 2543-2547.

26. Li, M.; Brooks, C.L.; Wu-Baer, F.; Chen, D.; Baer, R.; Gu, W. Mono-versus polyubiquitination: Differential control of 553 fate by Mdm2. Science 2003, 302, 1972-1975.

27. Montes de Oca Luna, R.; Wagner, D.S.; Lozano, G. Rescue of early embryonic lethality in mdm2-deficient mice by deletion of p53. Nature 1995, 378, 203-206.

28. Jones, S.N.; Roe, A.E.; Donehower, L.A.; Bradley, A. Rescue of embryonic lethality in Mdm2-deficient mice by absence of p53. Nature 1995, 378, 206-208.

29. Brady, C.A.; Attardi, L.D. p53 at a glance. J. Cell Sci. 2010, 123, 2527-2532.

30. Zhang, Y.; Lu, H. Signaling to p53: Ribosomal proteins find their way. Cancer Cell 2009, 16, 369-377.

31. Zhao, H.; Bauzon, F.; Fu, H.; Lu, Z.; Cui, J.; Nakayama, K.; Nakayama, K.I.; Locker, J.; Zhu, L. Skp2 deletion unmasks a p27 safeguard that blocks tumorigenesis in the absence of pRb and p53 tumor suppressors. Cancer Cell 2013, 24, 645-659.

32. Appella, E.; Anderson, C.W. Post-translational modifications and activation of p53 by genotoxic stresses. Eur. J. Biochem. 2001, 268, 2764-2772.

33. Shieh, S.Y.; Ikeda, M.; Taya, Y.; Prives, C. DNA damage-induced phosphorylation of p53 alleviates inhibition by MDM2. Cell 1997, 91, 325-334.

34. Shieh, S.Y.; Ahn, J.; Tamai, K.; Taya, Y.; Prives, C. The human homologs of checkpoint kinases Chk1 and Cds1 (Chk2) phosphorylate p53 at multiple DNA damage-inducible sites. Genes Dev. 2000, 14, 289-300.

35. Gu, W.; Roeder, R.G. Activation of p53 sequence-specific DNA binding by acetylation of the p53 C-terminal domain. Cell 1997, 90, 595-606.

36. Sakaguchi, K.; Herrera, J.E.; Saito, S.; Miki, T.; Bustin, M.; Vassilev, A.; Anderson, C.W.; Appella, E. DNA damage activates p53 through a phosphorylation-acetylation cascade. Genes Dev. 1998, 12, 2831-2841.

37. Liu, L.; Scolnick, D.M.; Trievel, R.C.; Zhang, H.B.; Marmorstein, R.; Halazonetis, T.D.; Berger, S.L. p53 sites acetylated in vitro by PCAF and p300 are acetylated in vivo in response to DNA damage. Mol. Cell. Biol. 1999, 19, 1202-1209.

38. Tang, Y.; Luo, J.; Zhang, W.; Gu, W. Tip60-dependent acetylation of p53 modulates the decision between cell-cycle arrest and apoptosis. Mol. Cell 2006, 24, 827-839.

39. Sykes, S.M.; Mellert, H.S.; Holbert, M.A.; Li, K.; Marmorstein, R.; Lane, W.S.; McMahon, S.B. Acetylation of the p53 DNA-binding domain regulates apoptosis induction. Mol. Cell 2006, 24, 841-851.

40. Kruse, J.P.; Gu, W. Modes of p53 regulation. Cell 2009, 137, 609-622.

41. Carmeliet, P.; Dor, Y.; Herbert, J.M.; Fukumura, D.; Brusselmans, K.; Dewerchin, M.; Neeman, M.; Bono, F.; Abramovitch, R.; Maxwell, P.; et al. Role of HIF-1alpha in hypoxia-mediated apoptosis, cell proliferation and tumour angiogenesis. Nature 1998, 394, 485-490. 
42. An, W.G.; Kanekal, M.; Simon, M.C.; Maltepe, E.; Blagosklonny, M.V.; Neckers, L.M. Stabilization of wild-type p53 by hypoxia-inducible factor 1alpha. Nature 1998, 392, 405-408.

43. Hammond, E.M.; Denko, N.C.; Dorie, M.J.; Abraham, R.T.; Giaccia, A.J. Hypoxia links ATR and p53 through replication arrest. Mol. Cell. Biol. 2002, 22, 1834-1843.

44. Lee, J.H.; Jin, Y.; He, G.; Zeng, S.X.; Wang, Y.V.; Wahl, G.M.; Lu, H. Hypoxia activates tumor suppressor $\mathrm{p} 53$ by inducing ATR-Chk1 kinase cascade-mediated phosphorylation and consequent 14-3-3 gamma inactivation of MDMX protein. J. Biol. Chem. 2012, 287, 20898-20903.

45. Zhou, X.; Liao, J.M.; Liao, W.J.; Lu, H. Scission of the p53-MDM2 Loop by Ribosomal Proteins. Genes Cancer 2012, 3, 298-310.

46. Marechal, V.; Elenbaas, B.; Piette, J.; Nicolas, J.C.; Levine, A.J. The ribosomal L5 protein is associated with mdm-2 and mdm-2-p53 complexes. Mol. Cell. Biol. 1994, 14, 7414-7420.

47. Lohrum, M.A.; Ludwig, R.L.; Kubbutat, M.H.; Hanlon, M.; Vousden, K.H. Regulation of HDM2 activity by the ribosomal protein L11. Cancer Cell 2003, 3, 577-587.

48. Zhang, Y.; Wolf, G.W.; Bhat, K.; Jin, A.; Allio, T.; Burkhart, W.A.; Xiong, Y. Ribosomal protein L11 negatively regulates oncoprotein MDM2 and mediates a p53-dependent ribosomal-stress checkpoint pathway. Mol. Cell. Biol. 2003, 23, 8902-8912.

49. Dai, M.S.; Lu, H. Inhibition of MDM2-mediated p53 ubiquitination and degradation by ribosomal protein L5. J. Biol. Chem. 2004, 279, 44475-44482.

50. Dai, M.S.; Zeng, S.X.; Jin, Y.; Sun, X.X.; David, L.; Lu, H. Ribosomal protein L23 activates p53 by inhibiting MDM2 function in response to ribosomal perturbation but not to translation inhibition. Mol. Cell. Biol. 2004, 24, 7654-7668.

51. Jin, A.; Itahana, K.; O'Keefe, K.; Zhang, Y. Inhibition of HDM2 and activation of p53 by ribosomal protein L23. Mol. Cell. Biol. 2004, 24, 7669-7680.

52. Bai, D.; Zhang, J.; Xiao, W.; Zheng, X. Regulation of the HDM2-p53 pathway by ribosomal protein L6 in response to ribosomal stress. Nucleic Acids Res. 2014, 42, 1799-1811.

53. Zhang, Y.; Wang, J.; Yuan, Y.; Zhang, W.; Guan, W.; Wu, Z.; Jin, C.; Chen, H.; Zhang, L.; Yang, X.; et al. Negative regulation of HDM2 to attenuate p53 degradation by ribosomal protein L26. Nucleic Acids Res. 2010, 38, 6544-6554.

54. Daftuar, L.; Zhu, Y.; Jacq, X.; Prives, C. Ribosomal proteins RPL37, RPS15 and RPS20 regulate the Mdm2-p53-MdmX network. PLoS One 2013, 8, e68667.

55. Yadavilli, S.; Mayo, L.D.; Higgins, M.; Lain, S.; Hegde, V.; Deutsch, W.A. Ribosomal protein S3: A multi-functional protein that interacts with both p53 and MDM2 through its KH domain. DNA Repair 2009, 8, 1215-1224.

56. Zhu, Y.; Poyurovsky, M.V.; Li, Y.; Biderman, L.; Stahl, J.; Jacq, X.; Prives, C. Ribosomal protein S7 is both a regulator and a substrate of MDM2. Mol. Cell 2009, 35, 316-326.

57. Chen, D.; Zhang, Z.; Li, M.; Wang, W.; Li, Y.; Rayburn, E.R.; Hill, D.L.; Wang, H.; Zhang, R. Ribosomal protein S7 as a novel modulator of p53-MDM2 interaction: Binding to MDM2, stabilization of p53 protein, and activation of p53 function. Oncogene 2007, 26, 5029-5037.

58. Zhou, X.; Hao, Q.; Liao, J.; Zhang, Q.; Lu, H. Ribosomal protein S14 unties the MDM2-p53 loop upon ribosomal stress. Oncogene 2013, 32, 388-396.

59. Zhang, X.; Wang, W.; Wang, H.; Wang, M.H.; Xu, W.; Zhang, R. Identification of ribosomal protein S25 (RPS25)-MDM2-p53 regulatory feedback loop. Oncogene 2013, 32, 2782-2791. 
60. Cui, D.; Li, L.; Lou, H.; Sun, H.; Ngai, S.M.; Shao, G.; Tang, J. The ribosomal protein S26 regulates p53 activity in response to DNA damage. Oncogene 2014, 33, 2225-2235.

61. Xiong, X.; Zhao, Y.; He, H.; Sun, Y. Ribosomal protein S27-like and S27 interplay with p53-MDM2 axis as a target, a substrate and a regulator. Oncogene 2011, 30, 1798-1811.

62. Sun, X.X.; DeVine, T.; Challagundla, K.B.; Dai, M.S. Interplay between ribosomal protein S27a and MDM2 protein in p53 activation in response to ribosomal stress. J. Biol. Chem. 2011, 286, 22730-22741.

63. Takagi, M.; Absalon, M.J.; McLure, K.G.; Kastan, M.B. Regulation of p53 translation and induction after DNA damage by ribosomal protein L26 and nucleolin. Cell 2005, 123, 49-63.

64. Ofir-Rosenfeld, Y.; Boggs, K.; Michael, D.; Kastan, M.B.; Oren, M. Mdm2 regulates p53 mRNA translation through inhibitory interactions with ribosomal protein L26. Mol. Cell 2008, 32, 180-189.

65. Mahata, B.; Sundqvist, A.; Xirodimas, D.P. Recruitment of RPL11 at promoter sites of p53-regulated genes upon nucleolar stress through NEDD8 and in an Mdm2-dependent manner. Oncogene 2012, 31, 3060-3071.

66. Macias, E.; Jin, A.; Deisenroth, C.; Bhat, K.; Mao, H.; Lindstrom, M.S.; Zhang, Y. An ARF-independent c-MYC-activated tumor suppression pathway mediated by ribosomal protein-Mdm2 Interaction. Cancer Cell 2010, 18, 231-243.

67. Lindstrom, M.S.; Jin, A.; Deisenroth, C.; White Wolf, G.; Zhang, Y. Cancer-associated mutations in the MDM2 zinc finger domain disrupt ribosomal protein interaction and attenuate MDM2-induced p53 degradation. Mol. Cell. Biol. 2007, 27, 1056-1068.

68. Sasaki, M.; Kawahara, K.; Nishio, M.; Mimori, K.; Kogo, R.; Hamada, K.; Itoh, B.; Wang, J.; Komatsu, Y.; Yang, Y.R.; et al. Regulation of the MDM2-P53 pathway and tumor growth by PICT1 via nucleolar RPL11. Nat. Med. 2011, 17, 944-951.

69. Fregoso, O.I.; Das, S.; Akerman, M.; Krainer, A.R. Splicing-factor oncoprotein SRSF1 stabilizes p53 via RPL5 and induces cellular senescence. Mol. Cell 2013, 50, 56-66.

70. Dai, M.S.; Challagundla, K.B.; Sun, X.X.; Palam, L.R.; Zeng, S.X.; Wek, R.C.; Lu, H. Physical and functional interaction between ribosomal protein L11 and the tumor suppressor ARF. J. Biol. Chem. 2012, 287, 17120-17129.

71. Kino, K.; Yamashita, A.; Yamaoka, K.; Watanabe, J.; Tanaka, S.; Ko, K.; Shimizu, K.; Tsunoo, H. Isolation and characterization of a new immunomodulatory protein, ling zhi-8 (LZ-8), from Ganoderma lucidium. J. Biol. Chem. 1989, 264, 472-478.

72. Wu, C.T.; Lin, T.Y.; Hsu, H.Y.; Sheu, F.; Ho, C.M.; Chen, E.I. Ling Zhi-8 mediates p53-dependent growth arrest of lung cancer cells proliferation via the ribosomal protein S7-MDM2-p53 pathway. Carcinogenesis 2011, 32, 1890-1896.

73. Sundqvist, A.; Liu, G.; Mirsaliotis, A.; Xirodimas, D.P. Regulation of nucleolar signalling to p53 through NEDDylation of L11. EMBO Rep. 2009, 10, 1132-1139.

74. Zhang, J.; Bai, D.; Ma, X.; Guan, J.; Zheng, X. hCINAP is a novel regulator of ribosomal protein-HDM2-p53 pathway by controlling NEDDylation of ribosomal protein S14. Oncogene 2014, 33, 246-254. 
75. Wilson-Edell, K.A.; Kehasse, A.; Scott, G.K.; Yau, C.; Rothschild, D.E.; Schilling, B.; Gabriel, B.S.; Yevtushenko, M.A.; Hanson, I.M.; Held, J.M.; et al. RPL24: A potential therapeutic target whose depletion or acetylation inhibits polysome assembly and cancer cell growth. Oncotarget 2014, 5, 5165-5176.

76. Ventimiglia, F.A.; Wool, I.G. A kinase that transfers the gamma-phosphoryl group of GTP to proteins of eukaryotic 40S ribosomal subunits. Proc. Nat. Acad. Sci. USA 1974, 71, 350-354.

77. Choudhary, C.; Kumar, C.; Gnad, F.; Nielsen, M.L.; Rehman, M.; Walther, T.C.; Olsen, J.V.; Mann, M. Lysine acetylation targets protein complexes and co-regulates major cellular functions. Science 2009, 325, 834-840.

78. Green, D.R.; Kroemer, G. Cytoplasmic functions of the tumour suppressor p53. Nature 2009, $458,1127-1130$.

79. Funk, W.D.; Pak, D.T.; Karas, R.H.; Wright, W.E.; Shay, J.W. A transcriptionally active DNA-binding site for human p53 protein complexes. Mol. Cell. Biol. 1992, 12, 2866-2871.

80. El-Deiry, W.S.; Kern, S.E.; Pietenpol, J.A.; Kinzler, K.W.; Vogelstein, B. Definition of a consensus binding site for p53. Nat. Genet. 1992, 1, 45-49.

81. Levine, A.J.; Oren, M. The first 30 years of p53: Growing ever more complex. Nat. Rev. Cancer 2009, 9, 749-758.

82. Carvajal, L.A.; Manfredi, J.J. Another fork in the road-life or death decisions by the tumour suppressor p53. EMBO Rep. 2013, 14, 414-421.

83. Chen, X.; Ko, L.J.; Jayaraman, L.; Prives, C. p53 levels, functional domains, and DNA damage determine the extent of the apoptotic response of tumor cells. Genes Dev. 1996, 10, 2438-2451.

84. Resnick-Silverman, L.; St Clair, S.; Maurer, M.; Zhao, K.; Manfredi, J.J. Identification of a novel class of genomic DNA-binding sites suggests a mechanism for selectivity in target gene activation by the tumor suppressor protein p53. Genes Dev. 1998, 12, 2102-2107.

85. Inga, A.; Storici, F.; Darden, T.A.; Resnick, M.A. Differential transactivation by the p53 transcription factor is highly dependent on p53 level and promoter target sequence. Mol. Cell. Biol. 2002, 22, 8612-8625.

86. Weinberg, R.L.; Veprintsev, D.B.; Bycroft, M.; Fersht, A.R. Comparative binding of p53 to its promoter and DNA recognition elements. J. Mol. Biol. 2005, 348, 589-596.

87. Oda, K.; Arakawa, H.; Tanaka, T.; Matsuda, K.; Tanikawa, C.; Mori, T.; Nishimori, H.; Tamai, K.; Tokino, T.; Nakamura, Y.; et al. p53AIP1, a potential mediator of p53-dependent apoptosis, and its regulation by Ser-46-phosphorylated p53. Cell 2000, 102, 849-862.

88. Samuels-Lev, Y.; O’Connor, D.J.; Bergamaschi, D.; Trigiante, G.; Hsieh, J.K.; Zhong, S.; Campargue, I.; Naumovski, L.; Crook, T.; Lu, X. ASPP proteins specifically stimulate the apoptotic function of p53. Mol. Cell 2001, 8, 781-794.

89. Bergamaschi, D.; Samuels, Y.; Sullivan, A.; Zvelebil, M.; Breyssens, H.; Bisso, A.; del Sal, G.; Syed, N.; Smith, P.; Gasco, M.; et al. iASPP preferentially binds p53 proline-rich region and modulates apoptotic function of codon 72-polymorphic p53. Nat. Genet. 2006, 38, 1133-1141.

90. Bartel, D.P. MicroRNAs: Genomics, biogenesis, mechanism, and function. Cell 2004, 116, 281-297.

91. He, L.; He, X.; Lowe, S.W.; Hannon, G.J. microRNAs join the p53 network-another piece in the tumour-suppression puzzle. Nat. Rev. Cancer 2007, 7, 819-822. 
92. Suzuki, H.I.; Yamagata, K.; Sugimoto, K.; Iwamoto, T.; Kato, S.; Miyazono, K. Modulation of microRNA processing by p53. Nature 2009, 460, 529-533.

93. Hermeking, H. MicroRNAs in the p53 network: Micromanagement of tumour suppression. Nat. Rev. Cancer 2012, 12, 613-626.

94. Liao, J.M.; Cao, B.; Zhou, X.; Lu, H. New insights into p53 functions through its target microRNAs. J. Mol. Cell Biol. 2014, 6, 206-213.

95. He, L.; He, X.; Lim, L.P.; de Stanchina, E.; Xuan, Z.; Liang, Y.; Xue, W.; Zender, L.; Magnus, J.; Ridzon, D.; et al. A microRNA component of the p53 tumour suppressor network. Nature 2007, 447, 1130-1134.

96. Bommer, G.T.; Gerin, I.; Feng, Y.; Kaczorowski, A.J.; Kuick, R.; Love, R.E.; Zhai, Y.; Giordano, T.J.; Qin, Z.S.; Moore, B.B.; et al. p53-mediated activation of miRNA34 candidate tumor-suppressor genes. Curr. Biol. 2007, 17, 1298-1307.

97. Chang, T.C.; Wentzel, E.A.; Kent, O.A.; Ramachandran, K.; Mullendore, M.; Lee, K.H.; Feldmann, G.; Yamakuchi, M.; Ferlito, M.; Lowenstein, C.J.; et al. Transactivation of miR-34a by p53 broadly influences gene expression and promotes apoptosis. Mol. Cell 2007, 26, 745-752.

98. Raver-Shapira, N.; Marciano, E.; Meiri, E.; Spector, Y.; Rosenfeld, N.; Moskovits, N.; Bentwich, Z.; Oren, M. Transcriptional activation of miR-34a contributes to p53-mediated apoptosis. Mol. Cell 2007, 26, 731-743.

99. Christoffersen, N.R.; Shalgi, R.; Frankel, L.B.; Leucci, E.; Lees, M.; Klausen, M.; Pilpel, Y.; Nielsen, F.C.; Oren, M.; Lund, A.H. p53-independent upregulation of miR-34a during oncogene-induced senescence represses MYC. Cell Death Differ. 2010, 17, 236-245.

100. Tazawa, H.; Tsuchiya, N.; Izumiya, M.; Nakagama, H. Tumor-suppressive miR-34a induces senescence-like growth arrest through modulation of the E2F pathway in human colon cancer cells. Proc. Nat. Acad. Sci. USA 2007, 104, 15472-15477.

101. Kim, N.H.; Kim, H.S.; Kim, N.G.; Lee, I.; Choi, H.S.; Li, X.Y.; Kang, S.E.; Cha, S.Y.; Ryu, J.K.; Na, J.M.; et al. p53 and microRNA-34 are suppressors of canonical Wnt signaling. Sci. Signal. 2011, 4, doi:10.1126/scisignal.2001744.

102. Kim, N.H.; Kim, H.S.; Li, X.Y.; Lee, I.; Choi, H.S.; Kang, S.E.; Cha, S.Y.; Ryu, J.K.; Yoon, D.; Fearon, E.R.; et al. A p53/miRNA-34 axis regulates Snaill-dependent cancer cell epithelial-mesenchymal transition. J. Cell Biol. 2011, 195, 417-433.

103. Weeraratne, S.D.; Amani, V.; Neiss, A.; Teider, N.; Scott, D.K.; Pomeroy, S.L.; Cho, Y.J. miR-34a confers chemosensitivity through modulation of MAGE-A and p53 in medulloblastoma. Neuro-Oncology 2011, 13, 165-175.

104. Siemens, H.; Jackstadt, R.; Kaller, M.; Hermeking, H. Repression of c-Kit by p53 is mediated by miR-34 and is associated with reduced chemoresistance, migration and stemness. Oncotarget 2013, 4, 1399-1415.

105. Zhang, A.; Xu, M.; Mo, Y.Y. Role of the lncRNA-p53 regulatory network in cancer. J. Mol. Cell Biol. 2014, 6, 181-191.

106. Huarte, M.; Guttman, M.; Feldser, D.; Garber, M.; Koziol, M.J.; Kenzelmann-Broz, D.; Khalil, A.M.; Zuk, O.; Amit, I.; Rabani, M.; et al. A large intergenic noncoding RNA induced by p53 mediates global gene repression in the p53 response. Cell 2010, 142, 409-419. 
107. Burns, M.B.; Lackey, L.; Carpenter, M.A.; Rathore, A.; Land, A.M.; Leonard, B.; Refsland, E.W.; Kotandeniya, D.; Tretyakova, N.; Nikas, J.B.; et al. APOBEC3B is an enzymatic source of mutation in breast cancer. Nature 2013, 494, 366-370.

108. Chan, W.M.; Siu, W.Y.; Lau, A.; Poon, R.Y. How many mutant p53 molecules are needed to inactivate a tetramer? Mol. Cell. Biol. 2004, 24, 3536-3551.

109. Xu, J.; Reumers, J.; Couceiro, J.R.; de Smet, F.; Gallardo, R.; Rudyak, S.; Cornelis, A.; Rozenski, J.; Zwolinska, A.; Marine, J.C.; et al. Gain of function of mutant p53 by coaggregation with multiple tumor suppressors. Nat. Chem. Biol. 2011, 7, 285-295.

110. Di Como, C.J.; Gaiddon, C.; Prives, C. p73 function is inhibited by tumor-derived p53 mutants in mammalian cells. Mol. Cell. Biol. 1999, 19, 1438-1449.

111. Marin, M.C.; Jost, C.A.; Brooks, L.A.; Irwin, M.S.; O’Nions, J.; Tidy, J.A.; James, N.; McGregor, J.M.; Harwood, C.A.; Yulug, I.G.; et al. A common polymorphism acts as an intragenic modifier of mutant p53 behaviour. Nat. Genet. 2000, 25, 47-54.

112. Gaiddon, C.; Lokshin, M.; Ahn, J.; Zhang, T.; Prives, C. A subset of tumor-derived mutant forms of p53 down-regulate p63 and p73 through a direct interaction with the p53 core domain. Mol. Cell. Biol. 2001, 21, 1874-1887.

113. Strano, S.; Fontemaggi, G.; Costanzo, A.; Rizzo, M.G.; Monti, O.; Baccarini, A.; del Sal, G.; Levrero, M.; Sacchi, A.; Oren, M.; et al. Physical interaction with human tumor-derived p53 mutants inhibits p63 activities. J. Biol. Chem. 2002, 277, 18817-18826.

114. Di Agostino, S.; Strano, S.; Emiliozzi, V.; Zerbini, V.; Mottolese, M.; Sacchi, A.; Blandino, G.; Piaggio, G. Gain of function of mutant p53: The mutant p53/NF-Y protein complex reveals an aberrant transcriptional mechanism of cell cycle regulation. Cancer Cell 2006, 10, 191-202.

115. Freed-Pastor, W.A.; Mizuno, H.; Zhao, X.; Langerod, A.; Moon, S.H.; Rodriguez-Barrueco, R.; Barsotti, A.; Chicas, A.; Li, W.; Polotskaia, A.; et al. Mutant p53 disrupts mammary tissue architecture via the mevalonate pathway. Cell 2012, 148, 244-258.

116. Bargonetti, J.; Chicas, A.; White, D.; Prives, C. p53 represses Sp1 DNA binding and HIV-LTR directed transcription. Cell. Mol. Biol. 1997, 43, 935-949.

117. Sampath, J.; Sun, D.; Kidd, V.J.; Grenet, J.; Gandhi, A.; Shapiro, L.H.; Wang, Q.; Zambetti, G.P.; Schuetz, J.D. Mutant p53 cooperates with ETS and selectively up-regulates human MDR1 not MRP1. J. Biol. Chem. 2001, 276, 39359-39367.

118. Do, P.M.; Varanasi, L.; Fan, S.; Li, C.; Kubacka, I.; Newman, V.; Chauhan, K.; Daniels, S.R.; Boccetta, M.; Garrett, M.R.; et al. Mutant p53 cooperates with ETS2 to promote etoposide resistance. Genes Dev. 2012, 26, 830-845.

119. Stambolsky, P.; Tabach, Y.; Fontemaggi, G.; Weisz, L.; Maor-Aloni, R.; Siegfried, Z.; Shiff, I.; Kogan, I.; Shay, M.; Kalo, E.; et al. Modulation of the vitamin D3 response by cancer-associated mutant p53. Cancer Cell 2010, 17, 273-285.

120. Gohler, T.; Jager, S.; Warnecke, G.; Yasuda, H.; Kim, E.; Deppert, W. Mutant p53 proteins bind DNA in a DNA structure-selective mode. Nucleic Acids Res. 2005, 33, 1087-1100.

121. Brazdova, M.; Quante, T.; Togel, L.; Walter, K.; Loscher, C.; Tichy, V.; Cincarova, L.; Deppert, W.; Tolstonog, G.V. Modulation of gene expression in U251 glioblastoma cells by binding of mutant p53 R273H to intronic and intergenic sequences. Nucleic Acids Res. 2009, 37, 1486-1500. 
122. Liu, K.; Ling, S.; Lin, W.C. TopBP1 mediates mutant p53 gain of function through NF-Y and p63/p73. Mol. Cell. Biol. 2011, 31, 4464-4481.

123. Girardini, J.E.; Napoli, M.; Piazza, S.; Rustighi, A.; Marotta, C.; Radaelli, E.; Capaci, V.; Jordan, L.; Quinlan, P.; Thompson, A.; et al. A Pin1/mutant p53 axis promotes aggressiveness in breast cancer. Cancer Cell 2011, 20, 79-91.

124. Vassilev, L.T.; Vu, B.T.; Graves, B.; Carvajal, D.; Podlaski, F.; Filipovic, Z.; Kong, N.; Kammlott, U.; Lukacs, C.; Klein, C.; et al. In vivo activation of the p53 pathway by small-molecule antagonists of MDM2. Science 2004, 303, 844-848.

125. Tovar, C.; Graves, B.; Packman, K.; Filipovic, Z.; Higgins, B.; Xia, M.; Tardell, C.; Garrido, R.; Lee, E.; Kolinsky, K.; et al. MDM2 small-molecule antagonist RG7112 activates p53 signaling and regresses human tumors in preclinical cancer models. Cancer Res. 2013, 73, 2587-2597.

126. Zak, K.; Pecak, A.; Rys, B.; Wladyka, B.; Domling, A.; Weber, L.; Holak, T.A.; Dubin, G. Mdm2 and MdmX inhibitors for the treatment of cancer: A patent review (2011-present). Expert Opin. Ther. Pat. 2013, 23, 425-448.

127. Vaziri, H.; Dessain, S.K.; Ng Eaton, E.; Imai, S.I.; Frye, R.A.; Pandita, T.K.; Guarente, L.; Weinberg, R.A. hSIR2(SIRT1) functions as an NAD-dependent p53 deacetylase. Cell 2001, 107, 149-159.

128. Luo, J.; Nikolaev, A.Y.; Imai, S.; Chen, D.; Su, F.; Shiloh, A.; Guarente, L.; Gu, W. Negative control of p53 by Sir2alpha promotes cell survival under stress. Cell 2001, 107, 137-148.

129. Lain, S.; Hollick, J.J.; Campbell, J.; Staples, O.D.; Higgins, M.; Aoubala, M.; McCarthy, A.; Appleyard, V.; Murray, K.E.; Baker, L.; et al. Discovery, in vivo activity, and mechanism of action of a small-molecule p53 activator. Cancer Cell 2008, 13, 454-463.

130. Zhang, Q.; Zeng, S.X.; Zhang, Y.; Ding, D.; Ye, Q.; Meroueh, S.O.; Lu, H. A small molecule Inauhzin inhibits SIRT1 activity and suppresses tumour growth through activation of p53. EMBO Mol. Med. 2012, 4, 298-312.

131. Tessoulin, B.; Descamps, G.; Moreau, P.; Maiga, S.; Lode, L.; Godon, C.; Marionneau-Lambot, S.; Oullier, T.; le Gouill, S.; Amiot, M.; et al. PRIMA-1Met induces myeloma cell death independent of p53 by impairing the GSH/ROS balance. Blood 2014, 124, 1626-1636.

132. Peng, X.; Zhang, M.Q.; Conserva, F.; Hosny, G.; Selivanova, G.; Bykov, V.J.; Arner, E.S.; Wiman, K.G. APR-246/PRIMA-1 ${ }^{\mathrm{MET}}$ inhibits thioredoxin reductase 1 and converts the enzyme to a dedicated NADPH oxidase. Cell Death Dis. 2013, 4, doi:10.1038/cddis.2013.417.

133. Rokaeus, N.; Shen, J.; Eckhardt, I.; Bykov, V.J.; Wiman, K.G.; Wilhelm, M.T. PRIMA-1(MET)/APR-246 targets mutant forms of p53 famly members p63 and p73. Oncogene 2010, 29, 6442-6451.

134. Bykov, V.J.; Issaeva, N.; Shilov, A.; Hultcrantz, M.; Pugacheva, E.; Chumakov, P.; Bergman, J.; Wiman, K.G.; Selivanova, G. Restoration of the tumor suppressor function to mutant p53 by a low-molecular-weight compound. Nat. Med. 2002, 8, 282-288.

135. Zandi, R.; Selivanova, G.; Christensen, C.L.; Gerds, T.A.; Willumsen, B.M.; Poulsen, H.S. PRIMA-1Met/APR-246 induces apoptosis and tumor growth delay in small cell lung cancer expressing mutant p53. Clin. Cancer Res. 2011, 17, 2830-2841. 
136. Lehmann, S.; Bykov, V.J.; Ali, D.; Andren, O.; Cherif, H.; Tidefelt, U.; Uggla, B.; Yachnin, J.; Juliusson, G.; Moshfegh, A.; et al. Targeting p53 in vivo: A first-in-human study with p53-targeting compound APR-246 in refractory hematologic malignancies and prostate cancer. J. Clin. Oncol. 2012, 30, 3633-3639.

137. Lambert, J.M.; Gorzov, P.; Veprintsev, D.B.; Soderqvist, M.; Segerback, D.; Bergman, J.; Fersht, A.R.; Hainaut, P.; Wiman, K.G.; Bykov, V.J. PRIMA-1 reactivates mutant p53 by covalent binding to the core domain. Cancer Cell 2009, 15, 376-388.

138. Boeckler, F.M.; Joerger, A.C.; Jaggi, G.; Rutherford, T.J.; Veprintsev, D.B.; Fersht, A.R. Targeted rescue of a destabilized mutant of p53 by an in silico screened drug. Proc. Nat. Acad. Sci. USA 2008, 105, 10360-10365.

139. Liu, X.; Wilcken, R.; Joerger, A.C.; Chuckowree, I.S.; Amin, J.; Spencer, J.; Fersht, A.R. Small molecule induced reactivation of mutant p53 in cancer cells. Nucleic Acids Res. 2013, 41, 6034-6044.

140. Yu, X.; Vazquez, A.; Levine, A.J.; Carpizo, D.R. Allele-specific p53 mutant reactivation. Cancer Cell 2012, 21, 614-625.

141. Khoo, K.H.; Verma, C.S.; Lane, D.P. Drugging the p53 pathway: Understanding the route to clinical efficacy. Nat. Rev. Drug Discov. 2014, 13, 217-236.

142. Zhang, Q.; Zeng, S.X.; Lu, H. Targeting p53-MDM2-MDMX Loop for Cancer Therapy. Subcell. Biochem. 2014, 85, 281-319.

143. Li, T.; Kon, N.; Jiang, L.; Tan, M.; Ludwig, T.; Zhao, Y.; Baer, R.; Gu, W. Tumor suppression in the absence of p53-mediated cell-cycle arrest, apoptosis, and senescence. Cell 2012, 149, 1269-1283.

144. Brady, C.A.; Jiang, D.; Mello, S.S.; Johnson, T.M.; Jarvis, L.A.; Kozak, M.M.; Kenzelmann Broz, D.; Basak, S.; Park, E.J.; McLaughlin, M.E.; et al. Distinct p53 transcriptional programs dictate acute DNA-damage responses and tumor suppression. Cell 2011, 145, 571-583.

145. Campisi, J. Parsing p53 Transactivation. Dev. Cell 2011, 20, 573-574.

(C) 2014 by the authors; licensee MDPI, Basel, Switzerland. This article is an open access article distributed under the terms and conditions of the Creative Commons Attribution license (http://creativecommons.org/licenses/by/4.0/). 